\title{
Analytical methods for assessing changes induced by gamma exposure in an animal model
}

Matheus F. Soares Mingote

(iD) Tarcísio P.R. Campos ${ }^{2}$

(iD) Rodinei Augusti ${ }^{3}$

(iD) Geovanni D. Cassali4

\begin{abstract}
1. Departamento de Engenharia Nuclear, Universidade Federal de Minas Gerais, Belo Horizonte, MG, Brasil 2. Professor Titular em Ciência da Radiação Aplicada à Saúde. Departamento de Engenharia Nuclear, Universidade Federal de Minas Gerais, Belo Horizonte, MG, Brasil

3. Professor titular em Química Analítica Avançada - Espectrometria de massa, Departamento de Química, Universidade Federal de Minas Gerais, Belo Horizonte, MG, Brasil

4. Professor titular do Departamento de Patologia Geral - ICB. Universidade Federal de Minas Gerais, Belo Horizonte, MG, Brasil
\end{abstract}

http://dx.doi.org/10.1590/1806-9282.66.12.1651

\section{SUMMARY}

OBJECTIVE: Ionizing radiation can cause radio-induced changes in the cellular metabolome due to the breakdown of DNA bonds. Our goal was to find the early tissue response to radiation exposure supported by distinct analytical methods.

METHODS: Histological analyses were performed on the organs extracted from rats to search for microscopic changes. The histological slides stained with hematoxyline-eosin (HE) were analyzed in magnification (40x). Subsequently, the tissues were subjected to mass spectrometry that allowed molecular analysis and DESI-MSI that generated the molecular image of lipids, assessing changes in intensities, especially in the brain.

RESULTS: The histological analysis found nonspecific inflammatory changes; no areas of fibrosis, necrosis, or apoptosis were identified, suggesting non-morphological tissue alterations. However, the DESI-MSI images of brain lipids allowed the observation of many radio-induced changes in the lipid's intensities.

CONCLUSIONS: No early radio induced histological or mass weight changes in the radiation exposed rats could be observed at 5 Gy. However, early changes in the molecular level were observed in the DESI-MSI images of the brain lipids. The DESI-MSI method proved to be efficient and relevant, allowing a regional molecular analysis of the tissues, expanding a new field of study that is still in its infancy: radiometabolomics.

KEYWORDS: Metabolome. Radiation. Gamma rays. Mass spectrometry. Lipids. Spectrometry, mass, matrix-assisted laser desorption-ionization. Brain.

\section{INTRODUCTION}

The International Cancer Research Agency of the World Health Organization (IARC/WHO) has shown that cancer is the leading cause of morbidity and mortality worldwide'.

The absence of repair mechanisms and control of the cell cycle allows the emergence of neoplastic lesions that characterize cancer ${ }^{2}$. One of the therapeutic modalities in cancer is radiotherapy, in which a large portion or the whole organ infiltrated by the tumor is exposed to radiation. Gamma radiation is a 
type of ionizing radiation (IR) that can cause various cellular damages due to direct and/or indirect structural changes resulting from the rupture of molecular bonds in the DNA of the neoplastic cells, resulting in their loss of clonogenicity ${ }^{3}$.

In addition, healthy tissues are also affected by radiation exposure, resulting in several adverse effects of the radiation therapy, such as cerebral edema, radiation necrosis, cerebral atrophy, neurocognitive deficits ${ }^{4}$, thickened bronchial wall, dilated alveolar space $^{5}$, pneumonitis, pulmonary fibrosis ${ }^{6}$, cardiomyopathy, reduction of myofibrils with fibrosis ${ }^{7}$, hepatocytes with focal necrosis, nephritis with glomerular capillary necrosis, or degeneration of the proximal cell lineage.

DESI-MSI is an analytical imaging method used to obtain lipid profiles of normal and neoplastic tissues, identify metabolites in microbiology, and study brain neurotransmitters ${ }^{8-11}$. Radio-induced brain changes can cause several adverse effects such as cognitive losses and radionecrosis ${ }^{12}$. DESI-MSI allows assessing changes in the tissue metabolic profile so that it can be used in a review of radiation therapy protocols in order to minimize the deleterious effects of ionizing radiation.

The goal of the present research was to find the early tissue response to the radiation exposure of total-body-irradiation (TBI) at 5 Gy supported by distinct analytical methods.

\section{METHODS}

\section{Group selection and Irradiation Protocol}

Statistical analyzes were performed with the body and organ mass weights of 40 male albino rats, 90 days old, from the Rattus norvegicus, Wistar line, weighing approximately $300 \pm 15 \mathrm{~g}$. The animals were euthanized, the organs removed, weighed, and stored. The tissues were prepared and histological and molecular analyses were performed. The research goals and protocols were previously submitted; the study was approved by the Ethics Committee on Animal Use (CEUA-UFMG), protocol 339/2014, after standardization for animal care; euthanasia. The animals of the IR group had their total body irradiated in the Co-60 Gamma-LIG/CDTN radiator, all together in 4 boxes, receiving 5 Gy absorbed dose, at the Laboratory of Irradiation Gamma-LIG of the Center of Development of the Nuclear Technology (CDTN). The irradiated animals were sacrificed according to time kinetics corresponding to $12 \mathrm{~h}, 48 \mathrm{~h}, 96 \mathrm{~h}$, and 01 week after exposure.

\section{Histological methods}

The organs were fixed at $10 \%$ buffered formalin and included in paraffin blocks. The $4 \mu \mathrm{m}$ sections were obtained and stained with hematoxylin and eosin (HE). The slides were evaluated by a pathologist, and the images were captured by a camera connected to an optical microscope (Olympus BX-40; Olympus, Tokyo, Japan). The histological analysis was performed on the tissue's images.

\section{DESI-MSI}

The solvents were acetonitrile and $\mathrm{N}, \mathrm{N}$-dimethyl formaldehyde ACN:DMF (1:1) since these chemical products do not cause morphological changes. The infusion pump was adjusted with a flow rate of 3.5 $\mu$ L.min ${ }^{-1}$. The nitrogen nebulizer gas was turned on at 160 psi pressure. The high voltage source was connected to the ion source and a voltage of $5 \mathrm{kV}$ applied. The mass spectra were acquired in the 200-1000 mass range, with an incidence angle of $\sim 54^{\circ}$ between the source and the sample surface. The analyses were made on a ThermoFisher Scientific Q executive Orbitrap MS instrument. The entire process is represented in Figure 1.

The ions were selected based on the changes in the intensity of the ions in the acquired images. In order to compare the control and experimental brain tissue with tissue responses in the respective time kinetics (24h, 48h, 96h, and 1 week), the ion intensities were properly equalized for comparison purposes.

\section{RESULTS}

\section{Histopathological analyses of organs}

Histological slides stained with HE were analyzed in magnification (40x), and the major histological characteristics found in the control group and the irradiated group were observed.

The histological brain slides from the irradiated group did not present changes such as inflammatory lymphomononuclear infiltrates, edemas, vascular degenerations, and areas of necrosis, as depicted in Figure 2. The lung plaques of the irradiated group did not present changes such as inflammatory lymphomononuclear infiltrates, exudates, edema, and thickening of the bronchial wall, as shown in Figure 2. 
FIGURE 1. SCHEMATIC REPRESENTATION OF THE DESI-MSI APPARATUS USED TO OBTAIN EACH TISSUE IMAGE.

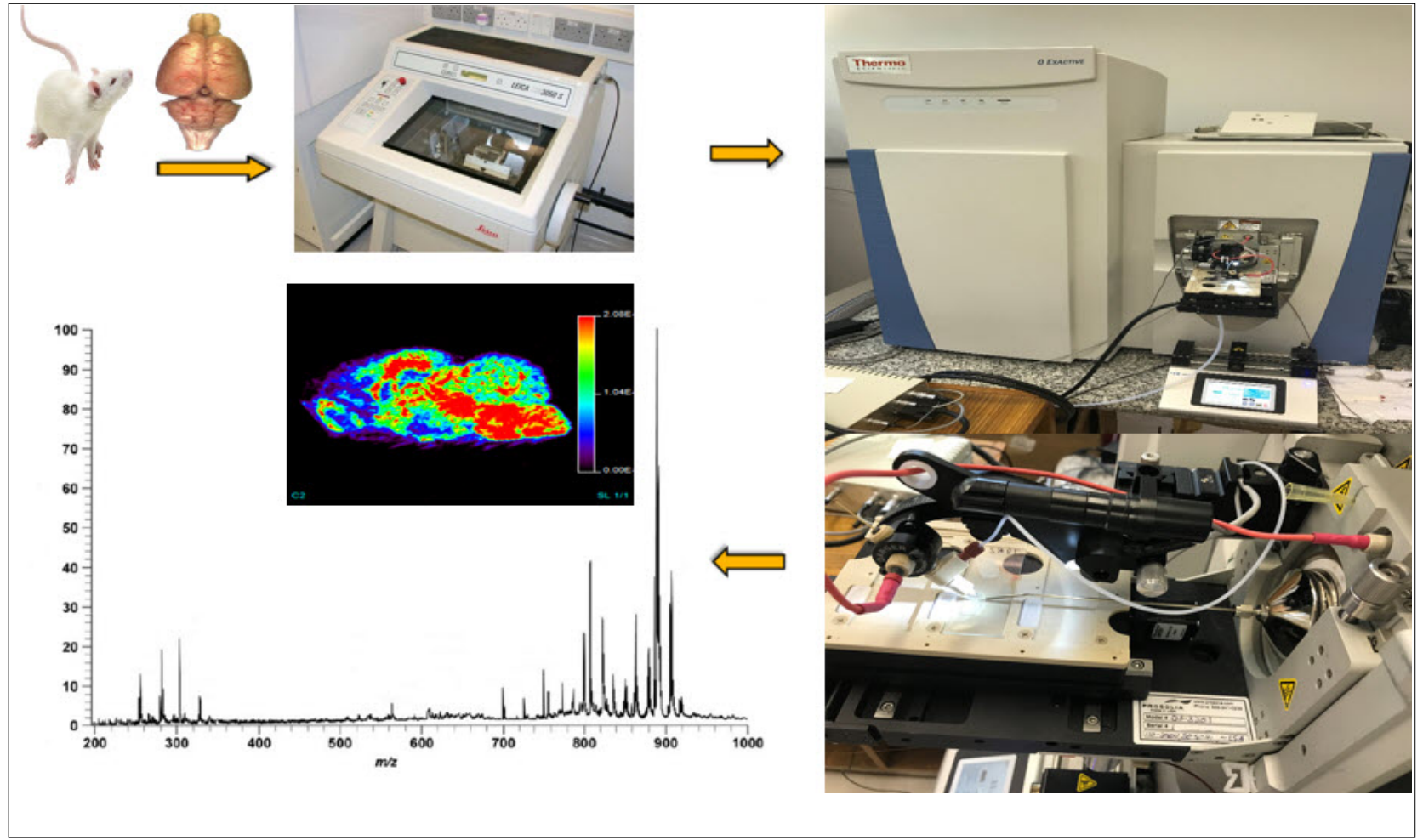

Source: Mingote ${ }^{12}$

FIGURE 2. BRAIN, LUNG, KIDNEY, LIVER, AND HEART 4OOX SLIDES

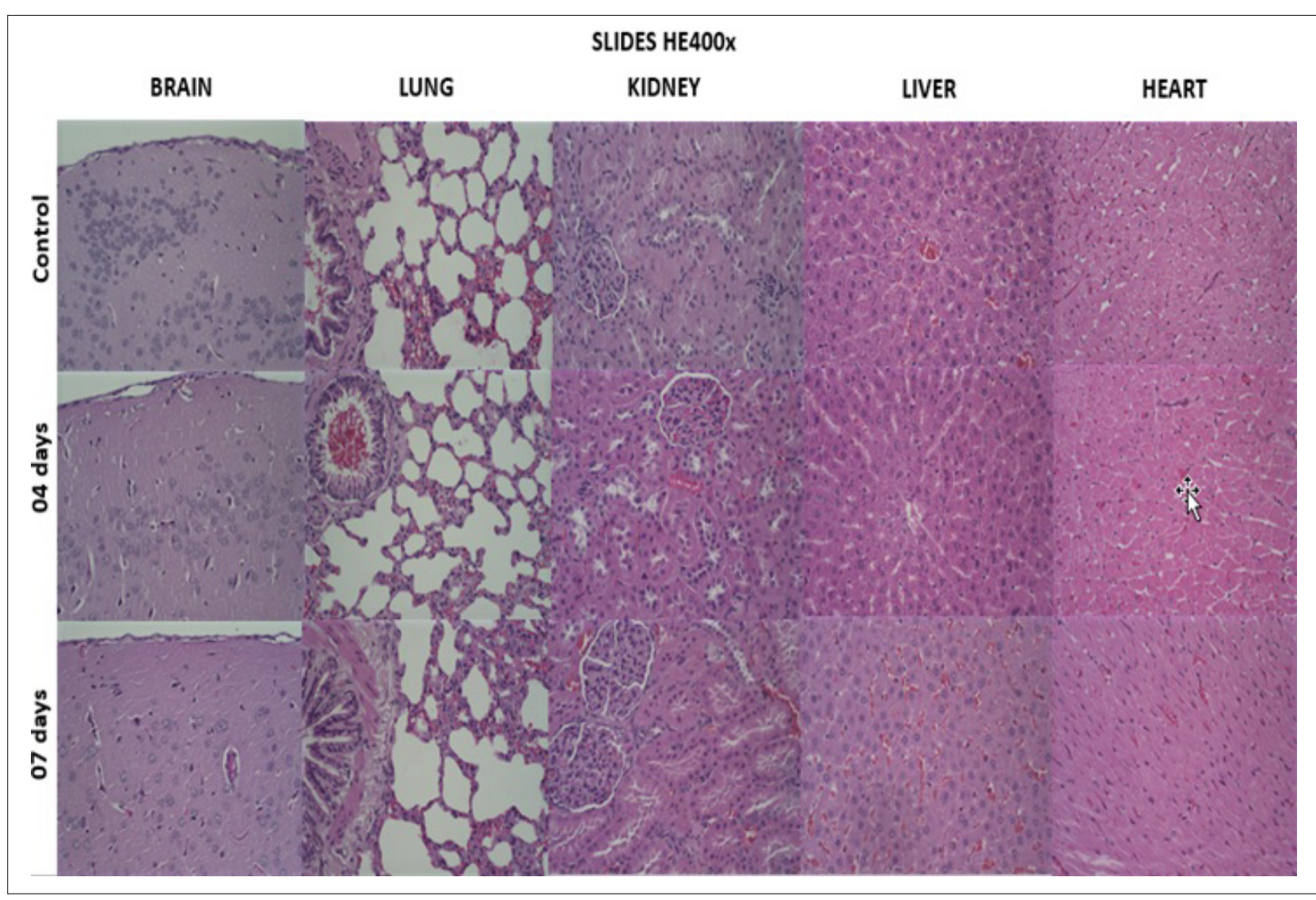

Source: Mingote ${ }^{12}$ 
The irradiated kidney slides showed no signs of focal or diffuse glomerulonephritis and no changes were observed such as inflammatory lymphomononuclear infiltrate, capillary necrosis, and cell degeneration in the proximal and distal tubules. The liver slides of the irradiated group had preserved architecture formed by hepatocyte cords, sinusoid capillaries, and centrilobular vein. No dilatation of sinusoidal capillaries, areas of focal necrosis, and cellular degeneration with vacuolated hepatocytes were observed. Figure 2 also shows the heart laminations of the irradiated group, demonstrating the preservation of the skeletal striated muscle structure without the presence of myofibrillar degeneration, areas of myofibrils necrosis, and areas of fibrosis.

\section{DESI images}

Pertinent changes were noticed in Ion images of the brain tissue of Wistar rats from samples of the control group and the irradiated group analyzed in DESI. The generated images referred to only one ion and were determined by its $\mathrm{m} / \mathrm{z}$ ratio. Thus, the scan reading of each pixel allowed the ions present at each point of the sample to be quantified and evaluated by their tissue distribution. Some ions were selected, which showed substantial differences in intensity and expressed in each organ area. Figure 3 shows the images of two ions obtained and their profile in the different regions of the Central Nervous System (CNS). The main changes observed were an abrupt modulation in lipid intensity in various regions for both samples.

\section{DISCUSSION}

Our findings show that the histological method did not reveal relevant changes in the levels of microscopic tissue.

Ionizing radiation has enough energy to cause electronic excitation, i.e., ionization, producing the breakdown of chemical bonds in the biological molecules (DNA, lipids, proteins) of tissues ${ }^{13,14}$. Lipid peroxidation is a cytotoxic process defined by successive biochemical events triggered by free radicals that determine the extensive oxidation of unsaturated fatty acids and membranes. The by-products of those processes

FIGURE 3. ION A) M/Z 794.622 AND B) ION M/Z 914.693. THE IMAGES REPRESENT THE INTENSITIES OF THE LIPID'S IONS, IN COLOR LEVELS, TAKEN IN A DISTINCT ANIMAL BRAIN SECTION, WHOSE PIXELS REPRESENT A SPECIFIC AREA OF THE RAT'S BRAIN, TAKEN AT THE AFTER-RADIATION TIMES OF 24H, 48H, 96H, AND 01 WEEK.

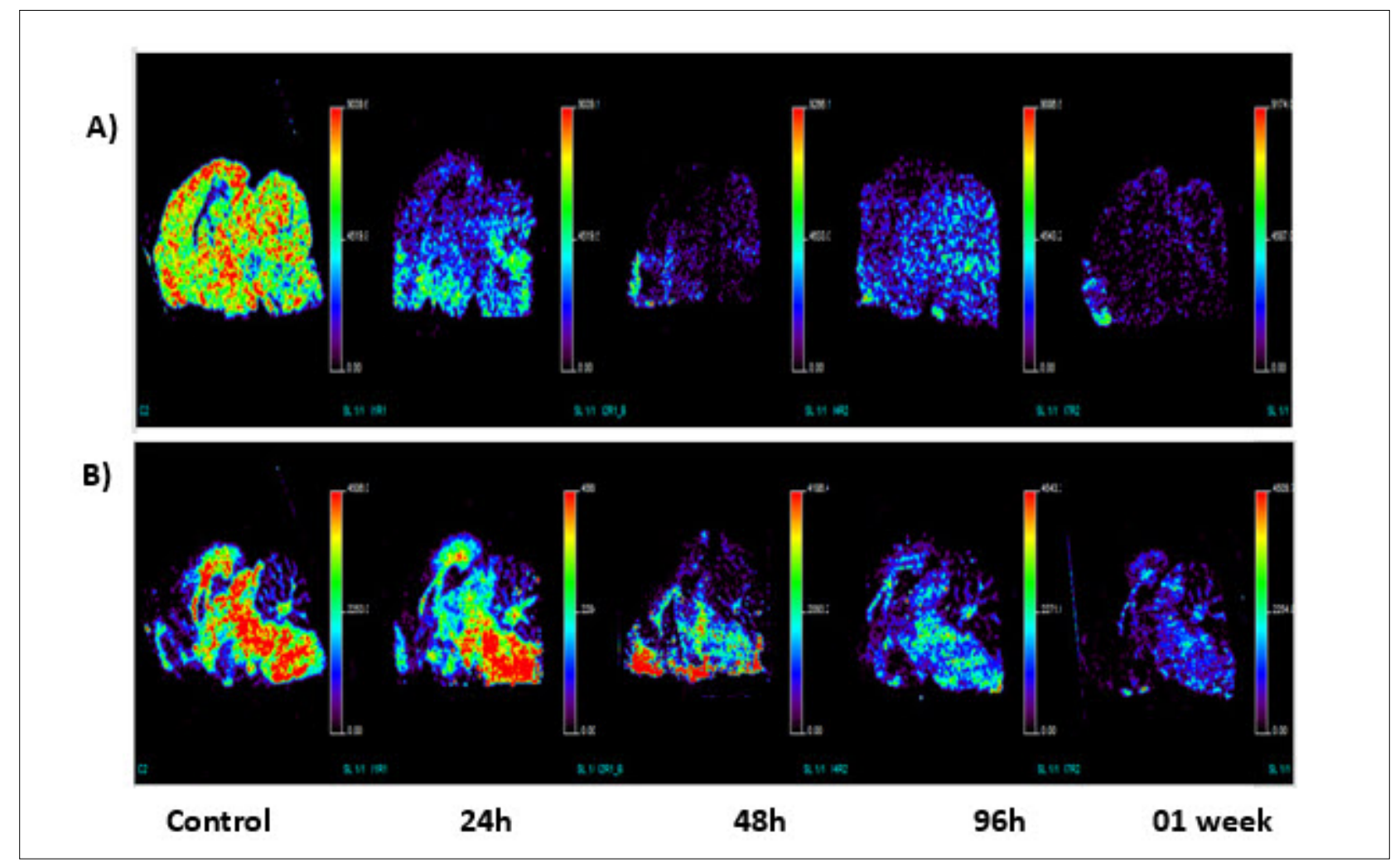

Source: Mingote ${ }^{12}$ 
induce structural and functional changes in the cell membrane, causing changes in the flow of the ionic and molecular substrate, triggering several biochemical changes. As an example, metabolism and serum phospholipid levels (PLs) were altered after exposure to ionizing radiation.

DESI, however, proved to be extremely effective in detecting important radio induced molecular changes ${ }^{15}$. Polyunsaturated fatty acids, as well as structural lipids of the cell membrane, are largely susceptible to damage caused by gamma irradiation. The results showed that the two selected lipids revealed significant changes in the CNS. The lipid distribution of $\mathrm{m} / \mathrm{z}$ 794,622 and m/z 914,693 from the control group to the irradiated groups was completely altered. The kinetics of time shows a change in lipid expression spatially in the brain, as well as an attempt to respond to minimize the damaging effects of radiation on tissues. After irradiation, an abrupt modulation in the intensity of this lipid was observed in all brain regions in the $24 \mathrm{~h}$ samples, and in the $48 \mathrm{hh}$ samples especially. The $96 \mathrm{~h}$ sample showed a slight diffuse increase; however, in the 01-week sample, there was a decrease in lipid intensity in all areas.

Changes in lipid expression lead to changes in signaling mechanisms for cellular and molecular repair. Molecular changes may be associated with the alteration and degeneration of myelin, present in numerous neurodegenerative diseases. It is still necessary to assess whether oxidative damage can lead to cell membrane dysfunction, causing changes in metabolism, selective change in cell permeability and signaling, which can lead to apoptosis ${ }^{14,16-18}$.

Molecular analyses in the other organs are still being developed since all research is maintained through inter-institutional cooperation to obtain data and images.

\section{CONCLUSIONS}

The effects of ionizing radiation must be better identified and understood at the molecular level. Although macroscopic and microscopic changes in the tissue are not yet evident, it is necessary to further deepen the techniques applied to the metabolic molecular analysis to achieve a better understanding of the mechanisms that can alter cell structures and function. DESI-MSI proved to be efficient and relevant, allowing regional molecular analysis of the entire CNS, expanding a new field of study that is still incipient: radiometabolomics. Our studies may contribute further to the review of the protocols in dose planimetry to minimize the deleterious effects of ionizing radiation.

\section{Acknowledgments}

We thank the Nuclear Technology Development Center (CDTN), especially Dr. Luis Ladeira, Gamma Irradiation Laboratory (LIG), due to the animal irradiations. Thanks to CAPES for the master's scholarship. We thank CNPq for the REBRAT/SUS project, 2013. We thank the institutional support of CAPES, CNPq, and FAPEMIG.

\section{Author's Contribution}

Study concept and design: MFSM, TPRC, RA; data acquisition: MFSM; data analysis/interpretation: MFSM, RA, GDC; supervision or mentorship: TPRC, RA, GDC. Each author contributed with important intellectual content during the manuscript drafting or revision and accepted accountability for the overall work of ensuring that questions pertaining to the accuracy or integrity of any portion of the work are appropriately investigated and resolved. MFSM takes responsibility that this study has been reported honestly, accurately, and transparently and that no important aspects of the study have been omitted.

\section{RESUMO}

OBJETIVO: Radiação ionizante pode causar alterações no metaboloma celular devido à quebra de ligações no DNA. O objetivo deste trabalho foi evidenciar a resposta aguda tecidual induzida pela exposição da radiação ionizante.

MÉTODOS: Análises histológicas foram realizadas nos órgãos extraídos de ratos para análise de alterações microscópicas. As lâminas histológicas coradas com hematoxilina eosina (HE) foram analisadas em aumento (40x). Posteriormente, os tecidos foram submetidos a espectrometria de massa, que permitiu análise molecular e o Desi-MSI que gerou imagem molecular de lipídios, identificando alterações na intensidade, principalmente no cérebro.

RESULTADOS: As análises histológicas encontraram alterações inflamatórias inespecíficas, nem áreas de fibrose, necrose ou apoptose, sugerindo ausência de alterações morfológicas. As imagens de lipídios cerebrais obtidas por Desi-MSI permitiram observar as inúmeras alterações na intensidade nas seções teciduais do encéfalo. 
CONCLUSÕES: Alterações agudas radioinduzidas de massa do órgão e histológicas nos órgãos dos ratos expostos não puderam ser observadas a 5 Gy. Entretanto, mudanças em nível molecular foram observadas nas imagens de Desi-MSI dos lipídios cerebrais. $O$ método Desi-MSI mostrou-se eficiente e relevante, permitindo a análise molecular regi-onal dos tecidos no SNC, expandindo um novo campo de estudo que ainda está em sua infância: a radiometaboloma.

PALAVRAS-CHAVE: Metaboloma. Radiação. Raios gama. Espectrometria de massa. Lipídios. Espectrometria de massas por ionização e dessorção a laser assistida por matriz. Encéfalo.

\section{REFERENCES}

1. Forman D, Ferlay |. The global and regional burden of cancer. In: Stewart BW, Wild CP, eds. World cancer report 2014. Lyon: International Agency for Research on Cancer, World Health Organization; 2014. p.16-53.

2. Hall EJ, Giaccia AJ. Radiobiology for the radiologist. $7^{\text {th }}$ ed. Philadelphia: Lippincott Williams and Wilkins; 2011.

3. Maia GA, Renó CO, Medina IM, Silveira AB, Mignaco |A, Atella GC, et al. The effect of gamma radiation on the lipid profile of irradiated red blood cells. Ann Hematol. 2014;93(5):753-60.

4. Lee AWM, Cheng LOC, Ng SH, Tse VKC, Au SKOGKH, Poon YF. Magnetic resonance imaging in the clinical diagnosis of late temporal lobe necrosis following radiotherapy for nasopharyngeal carcinoma. Clin Radiol. 1990;42(1):24-31

5. Fajardo LF. Morphology of radiation effects on normal tissues. In: Perez CA, Brady LW, eds. Principles and practices of radiation oncology. $2^{\text {nd }}$ ed. New York: Lippincott; 1992. p.114-23.

6. Gunderson LL, Tepper JE. Clinical radiation oncology. $4^{\text {th }}$ ed. Philadelphia: Elsevier; 2015.

7. Jafari B. Investigation of cobalt radiation on the heart of rat. | Basic Appl Sci Res. 2011;1(12):2932-4

8. Eberlin LS, Tibshirani R|, Zhang |, Longacre TA, Berry G|, Bingham DB, et al. Molecular assessment of surgical-resection margins of gastric cancer by mass-spectrometric imaging. Proc Natl Acad Sci U.S.A. 2014;111(7):2436-41.

9. Angolini CF, Vendramini PH, Araújo FD, Araújo WL, Augusti R, Eberlin $M N$, et al. Direct protocol for ambient mass spectrometry imaging on agar culture. Anal Chem. 2015;87(13):6925-30.
10. Correa DN, Zacca IJ, Rocha WFC, Borges R, Souza W, Augusti R, et al. Anti-theft device staining on banknotes detected by mass spectrometry imaging. Forensic Sci Int. 2016;260:22-6.

11. Fernandes AM, Vendramini PH, Galaverna R, Schwab NV, Alberici LC, Augusti $R$, et al. Direct visualization of neurotransmitters in rat brain slices by desorption electrospray ionization mass spectrometry imaging (DESI MS). J Am Soc Mass Spectrom. 2016;27(12):1944-51.

12. Mingote MFS. Análise lipídica de tecido cerebral expostos à radiação por DESI-MS [Dissertação de mestrado]. Belo Horizonte: Universidade Federal de Minas Gerais, Escola de Engenharia, Departamento de Engenharia Nuclear; 2017.

13. Yoshimura EM. Física das radiações: interação da radiação com a matéria. Rev Bras Física Méd. 2009;(1):57-67.

14. Kolomiytseva IK, Kulagina TP, Markevich LN, Archipov VI, Slozhenikina LV, Fialkovskaya LA, et al. Nuclear and chromatin lipids: metabolism in normal and gamma-irradiated rats. Bioelectrochemistry. 2002;58(1):31-9.

15. Mingote MFS, Campos TPR, Augusti R, Eberlin MN. Methodological issues in protein and lipidic expressions in brain tissue exposed to $\mathrm{CO}^{60}$ based on DESI/MALDI-MSI. Braz | Rad Sci. 2019;7(2A):1-13.

16. Ackerstaff E, Glunde K, Bhujwalla ZM. Choline phospholipid metabolism: a target in cancer cells? J Cell Biochem. 2003;90(3):525-33.

17. Wang C, Yang |, Nie J. Plasma phospholipid metabolic profiling; biomarkers of rats following radiation exposure based on liquid chromatography-mass spectrometry technique. Biomed Chromatogr. 2009;23(10):1079-85.

18. Gaber $\mathrm{MH}$. Effect of gamma-irradiation on the molecular properties of bovine serum albumin. | Biosci Bioeng. 2005;100(2):203-6. 